\title{
Effect of a Stoma Nursing Care Program on the Adjustment of Patients with an Ostomy*
}

Theme: Chronic disease care.

Contribution to the discipline: This research has important implications in health planning, particularly nursing, since it means that the adjustment to an ostomy improves significantly if patients receive differentiated care during the preoperative, immediate, and follow-up periods. The present study has strengths such as the importance of the enterostomal therapist's systematic intervention to promote a healthier adjustment.

\section{ABSTRACT}

Objective: To evaluate the effect of a stoma nursing care program on the personal adjustment to an ostomy. Materials and methods: A quasi-experimental study with a control group. The sample of 105 patients with stoma was divided into two groups (intervention group and control group), with assessments in the first and sixth month after hospital discharge. Information was collected using the Elimination Ostomy Adjustment Scale. Student's t-tests analysis were performed. Results: One month after hospital discharge, the adjustment to the stoma was satisfactory and similar $(p>0.05)$ in both groups, and in the sixth month, statistically more favorable in the intervention group $(p<0.001)$; a statistically significant difference between the two assessments $(p<0.001)$ is found in the intervention group only. Conclusions: The intervention program has a positive influence on the adjustment to the stoma, and its contribution is significant six months after hospital discharge. Systematic interventions of an ostomy care specialized nurse have shown positive effects on ostomy adjustment, which is recommended since the preoperative period.

KEYWORDS (Source: DeCS, MeSH)

Surgical stoma; psychological adjustment; nursing care; preoperative period; postoperative period.

DOI: 10.5294/aqui.2020.20.1.4

Para citar este artículo / To reference this article / Para citar este artigo

Fernandes CP, Brito CS. Effect of a Stoma Nursing Care Program on the Adjustment of Patients with an Ostomy. Aquichan. 2020;20(1):e2014. D0I: https://doi.org/10.5294/ aqui.2020.20.1.4

1 http://orcid.org/0000-0002-7536-3557. School of Health, Instituto Politécnico de Viana do Castelo, Portugal. clementinasousa@ess.ipvc.pt

2 http://orcid.org/0000-0001-9198-2668. Escola Superior de Enfermagem do Porto, Portugal. celiasantos@esenf.pt

* This article derives from a doctoral dissertation in the Advanced Nursing Specialty: "Criação e Avaliação de um Programa de Intervenção em Enfermagem de Estomaterapia: Contributos na Adaptação à Ostomia e Qualidade de Vida", authored by Clementina dos Prazeres Fernandes de Sousa. Universidade Católica Portuguesa, 2016.

Received: 08/11/2019

Sent to peer review: 12/12/2019

Accepted peer review: 02/02/2020

Approved: 18/02/2020 


\section{Efecto de un programa de atención de enfermería en estomaterapia en la adaptación de la persona a la ostomía de eliminación*}

\section{RESUMEN}

Objetivo: evaluar el efecto de un programa de atención de enfermería en estomaterapia en la adaptación de la persona a la ostomía de eliminación (OE). Materiales y métodos: estudio cuasiexperimental con grupo control. La muestra de 105 personas con OE se dividió en dos grupos (grupo de intervención y grupo de control), con evaluación en el primer y sexto mes después del alta hospitalaria. La información se recopiló mediante la Escala de Adaptación a la Ostomía de Eliminación. Se realizaron pruebas t de Student para el análisis estadístico. Resultados: en el primer mes después del alta hospitalaria, la adaptación a la OE fue satisfactoria y similar $(p>0,05)$ en los dos grupos y el sexto mes fue estadísticamente más favorable en el grupo de intervención $(p<0,001)$, con diferencias estadísticamente significativas en el grupo de intervención entre los dos momentos de evaluación $(p<0,001)$. Conclusiones: el programa influenció positivamente la adaptación a la OE y su contribución se hizo visible al sexto mes después del alta hospitalaria. La intervención sistemática de la enfermería en estomaterapia reveló un efecto favorable en la adaptación a la OE, por lo que es recomendable que se inicie en el período preoperatorio.

\section{PALABRAS CLAVE (Fuente: DeCS, MeSH)}

Estomas quirúrgicos; ajuste emocional; atención de enfermería; periodo preoperatorio; periodo posoperatorio.

\footnotetext{
* Este artículo se deriva de la tesis de doctorado: "Criação e Avaliação de um Programa de Intervenção em Enfermagem de Estomaterapia: Contributos na Adaptação à Ostomia e Qualidade de Vida", Universidade Católica Portuguesa, 2016.
} 


\section{Efeito de um programa de enfermagem em estomaterapia na adaptação da pessoa ao estoma de eliminação*}

\section{RESUMO}

Objetivo: avaliar 0 efeito de um programa de intervenção de enfermagem em estomaterapia na adaptação da pessoa à ostomia de eliminação (OE). Material e métodos: estudo quasi-experimental com grupo de controlo. A amostra de 105 pessoas com OE repartiu-se por dois grupos (grupo de intervenção e grupo de controlo), com avaliação ao primeiro e sexto mês depois da alta hospitalar. A informação foi recolhida com a Escala de Adaptação à Ostomia de Eliminação. Realizaram-se testes t-Student para análise estatística. Resultados: ao primeiro mês, a adaptação à OE era satisfatória e semelhante $(p>0,05)$ nos dois grupos, sendo ao sexto mês, estatisticamente mais favorável no grupo de intervenção ( $p<0,001)$; com diferenças estatisticamente significativas entre os dois momentos de avaliação ( $p$ $<0,001)$, no grupo de intervenção. Conclusões: 0 programa de intervenção influenciou positivamente 0 percurso de transição para a adaptação à $\mathrm{OE}$, sendo visível o seu contributo, ao sexto mês depois da alta hospitalar. A intervenção sistematizada da enfermeira estomaterapeuta revelou um efeito favorável na adaptação à $\mathrm{OE}$, sendo recomendável desde o período pré-operatório.

\section{PALAVRAS-CHAVE (Fonte: DeCS, MeSH)}

Estoma cirúrgico; ajustamento emocional; cuidados de enfermagem; período pré-operatório; período pós-operatório.

* Este artigo é derivado da tese de doutorado "Criação e Avaliação de um Programa de Intervenção em Enfermagem de Estomaterapia: Contributos na Adaptação à Ostomia e Qualidade de Vida", Universidade Católica Portuguesa, 2016. 


\section{Introduction}

An ostomy represents a potential threat to the dynamics of everyday life, which is expressed by emotional, physical, and social imbalance; therefore, individuals must learn a different modus vivendi and incorporate it into their daily life. Adjusting to a changed body generates responses that reflect in various ways to deal with the new condition, which implies the acquisition of new skills to adjust and move forward (1-6).

Being colorectal cancer the most common disease and colostomy one of the surgical proposals, the ghost of recurrence, the progression to terminal disease and subsequent death, and the stoma can continuously torment the patient's thinking, influencing his/her coping strategies and the adjustment process $(1,7,8)$. However, the fact that an ostomy represents disease control and allows to continue living can ease acceptance as well as transition to psychosocial adjustment $(7,9)$.

Adjustment includes the individual's intention and willingness to manage new situations and challenges (10). The adjustment to an ostomy means that the person will have to reorganize and redirect his/her life, face the changes, and accept new challenges knowing that they have a stoma $(3-5,11-13)$. If the stoma is permanent it will be with him/her for the rest of his/her lifetime, involving a smooth reformulation of his/her identity, body image, and new or renewed concept of life (2-5).

Given these assumptions, our research is based on Meleis' Transitions Theory, considering that ostomy surgery implies a health/illness transition. The conceptual basis of this theory supported the analysis and understanding of the nature of these phenomena and how people cope with changes in their bodies and self-care, as well as the factors associated with the adjustment to the transition to a life with an ostomy. It involves the awareness and commitment of the individual to accept the changes and the recognition of the personal potentials and the environmental resources that will enable them to overcome the transition period and adjust healthily to the new living conditions (14).

In this context, the potential of nursing therapeutics emerges, improving the strengthening capacities directed to stoma care management and the appropriation of a new sense of life. This empowerment that is built step by step will have an impact on the healthy adjustment to the changes perceived by people who start living with an ostomy. Thus, the incorporation of an ostomy and the reformulation of one's identity happen, and the health outcomes flow smoothly (14).

The identification of personal and environmental transition conditions (facilitators and inhibitors) will guide the educational action of nursing to allow the development of skills that help enjoy a more independent, more interactive, and healthier life (14). Nurses, particularly the enterostomal therapist nurses (ETN), face two major challenges. On the one hand, understanding the transition phase that patients are experiencing; on the other, providing them nursing therapeutics that promote, as far as possible, self-confidence, well-being, and autonomy $(3,11,14)$.

Several studies emphasize the effect of psychosocial adjustment to the ostomy if stoma nurses take care of patients $(3,6,11$, $13,15-20)$. If such intervention starts in the preoperative phase and continues after hospital discharge, it will strengthen their early involvement and management of self-care and the construction of more proactive attitudes toward the new life circumstances ( 1 , $18,19)$. The stoma self-care appropriation will be more effective if teaching strategies are structured and continued $(6,15)$.

There are numerous studies that analyze changes in self-care after bowel or urinary stoma and its implications for adjustment, discovering positive associations between stoma care autonomy and the adjustment to an ostomy $(12,13)$.

In this framework, this study was designed to assess the effect of a nursing program in enterostomal therapy (NPET) on ostomy adjustment. Considering the theoretical assumptions, scientific evidence, and purpose of our study, the following hypotheses were defined:

- $\mathrm{Hl}$ - Patients benefiting from the NPET have a better adjustment to the ostomy than those who have not received this intervention at the end of the first month after hospital discharge;

- $\mathrm{H} 2$ - Patients who have received care through the NPET have a better adjustment to the ostomy compared to those who received usual nursing care at the end of the sixth month after hospital discharge;

- H3 - Between the first and sixth months after hospital discharge, the adjustment to the ostomy improves significantly 
in those who were provided with the NPET, compared to those without this interv ention.

\section{Method}

An intervention nursing program (NPET) was created in a previous study, using a mixed-method sequential design, supported by the guidelines of the Medical Research Council for the development and evaluation of complex interventions. The study had two phases:

- Phase 1: Construction of a NPET pilot version based on theoretical nursing references, the International Classification for Nursing Practice (10) and the Nursing Interventions Classification (21), using the focus group technique, with a panel of seven expert nurses.

- Phase 2: Pilot study of the implementation of the program. Six focuses of the nursing practice (Self-concept, Self-care, Acceptance, Hope, Sexual Interaction, and Social Interaction) and nursing interventions that were considered relevant to the ostomized people care make up the NPET consensus version to be applied to the present study. The intervention program was applied in the preoperative, transoperative, and follow-up phase of patients with ostomy

This research is a quasi-experimental study with a control group (22) and involves an NPET and data collection at two points in time: first and sixth-months after hospital discharge (Table 1).

Table 1. Study design

\begin{tabular}{|c|c|c|c|c|c|}
\hline $\begin{array}{l}\text { 을 } \\
\text { 눈 }\end{array}$ & 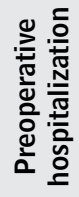 & 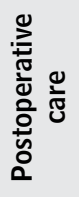 & 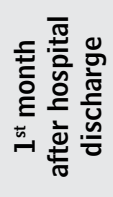 & 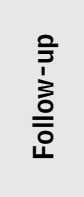 & 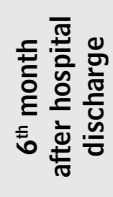 \\
\hline $\begin{array}{l}\text { Intervention } \\
\text { (IG) }\end{array}$ & X IEl & X IE2 & $\mathrm{Al}$ & $\begin{array}{l}X \mathrm{IE} 3 \\
n \geq 5\end{array}$ & A2 \\
\hline $\begin{array}{c}\text { Control } \\
\text { (CG) }\end{array}$ & & & $\mathrm{Al}$ & & A2 \\
\hline
\end{tabular}

Legend: X IEl - $1^{\text {st }}$ nursing intervention with NPET; X IE2 - $2^{\text {nd }}$ nursing intervention with NPET; $X$ IE3 - Follow-up nursing interventions with NPET. Al - $1^{\text {st }}$ moment of data collection; $A 2-2^{\text {nd }}$ moment of data collection.

Source: Own elaboration
The sample size was obtained during 2015 and 2016, in nine hospital units in northern Portugal. For the intervention group (IG) subjects from four hospitals with Stomatherapy Nursing Consultation (SNC) were selected and the participants allocated to the control group (CG) were from five hospitals without SNC or ETN. The criteria for inclusion in the sample include individuals hospitalized for ostomy elective surgery or even ostomy palliative surgery; with primary bowel or urinary stoma (temporary or permanent); aged 18 years or older, and study volunteers.

After obtaining their written informed consent in the first assessment, 105 subjects, 72 for the IG and 33 for the CG, comprise the sample. In the second assessment, there were 93 participants, of whom 61 were in the IG and 32 in the CG, with a death rate between both assessments of 15.3 and $3 \%$, respectively (Figure 1 ).

Figure 1. Flow diagram of study participants as per CONSORT (Northern Portugal)

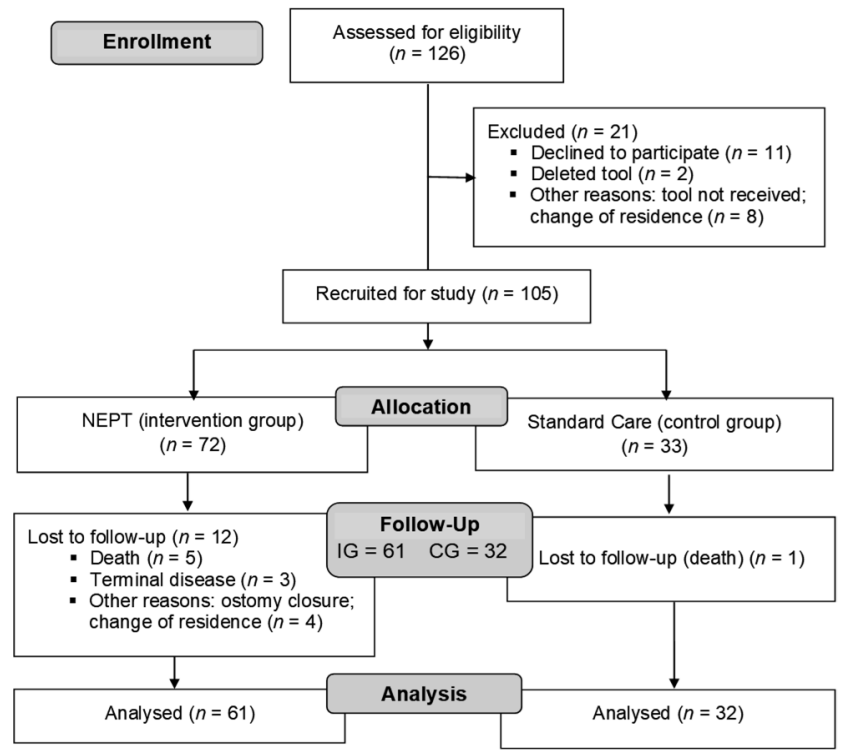

Source: Adapted from CONSORT 2010

During hospitalization, two visits of the ETN were planned in the intervention group to perform the NPET: one preoperative and another postoperative. Additionally, five follow-up consultations were programmed as a minimum for six months after discharge. More consultations could be planned according to the patient's needs. In the same period, the general nurses provided routine care | to both groups, in all the hospitals involved. 
A demographic and clinical characteristics questionnaire and the Elimination Ostomy Adjustment Scale (EOAS) $(23,24)$ were used as data collection instruments. The instruments were administered to the patients in two assessments: the first and sixth months after hospital discharge. The follow-up decision for this period was based on literature $(19,23)$, mentioning that around three to six months of ostomy experience are enough to develop new self-care skills, as well as a to improve adjustment gradually. Open-ended questions about self-care autonomy before surgery, co-morbidities, and causal disease were assessed in the first moment.

The EOAS was developed for this study in two phases:

- Phase 1: Development of the instrument. The initial version of the scale was analyzed by a committee of 25 experts for content validation and pre-tested on 20 ostomized patients.

- Phase 2: Study of its psychometric properties. It employed a sample of 256 participants, with bowel or urinary stoma (temporary or permanent), aged 18 years or older.

The EOAS contains 35 items that measure six ostomy adjustment domains: Self-concept, Self-care, Positive Acceptance, Negative Acceptance, Social/Religious Support, and Sexual Interaction, operationalized on a 7-point Likert scale, ranging from $1=$ strongly disagree to $7=$ totally agree. Fifteen items are reverse coded. In the original study, the Cronbach's alpha coefficients of the six domains were between $0.85-0.61$, while the overall scale was 0.87 .

The results are organized in a way that generates a score for each domain and on a global scale. To identify the mean scores, we used a formula that transforms the averages obtained into scores from 0 to 100 . A higher mean score corresponds to a more favorable ostomy adjustment.

Descriptive statistics were used with absolute frequency and percentage data of categorical variables to describe the sample profile. The calculation of position and dispersion measures (mean, standard deviation) was used for the continuous variables. To analyze the differences between the mean scores of two groups, independent sample t-test and paired sample t-test were used to analyze the effect size, with a margin of error of $5 \%$ ( $p \leq$ 0.05 ) and a confidence level of $95 \%$ (25). All data were analyzed using SPSS software, version 22.0 .
The research was conducted according to Decree-Law No. 97/95 of the Portuguese Republic, which regulates health ethics commissions, and approved by the ethics committees of the hospitals involved. For the administration of the instruments, verbal and written consent was requested from the participants. Anonymity and confidentiality of responses were ensured, and the Informed Consent Form was provided.

\section{Results}

In the first assessment (Table 2), the CG on average was older than the IG, 63, $55 \pm 10.13$ years and $58,38 \pm 16.35$ years, respectively. In the $\mathrm{IG}$, men predominated $(58.3 \%)$ while in the CG, women did $(60.6 \%)$. Most had completed the $1^{\text {st }}$ cycle of basic education (IG, $77.8 \%$ and CG, $90.9 \%$ ). Most of them were retired, although $47.2 \%$ of the IG participants and $27.3 \%$ of CG still practiced a profession. The majority were married/cohabiting (58.3\% of the IG and $60.6 \%$ of the CG). Approximately $28 \%$ of IG and $36 \%$ of CG were a widow(er), separated, or divorced. No variables showed statistical differences.

The members from the hospitals with SNC (IG subjects) received preoperative information from both the nurse and the surgeon (100 and $97.2 \%$, respectively). In contrast, at hospitals without SNC (CG subjects), only $12.1 \%$ of them received information from the nurse and $66.7 \%$ from the surgeon. Regarding demographic variables, the groups were statistically equivalent $(p>0.05)$ in age, gender, marital status, education level, and occupation. Significant differences were observed in the preoperative information.

Table 2. Demographic characterization of the sample for the first assessment

\begin{tabular}{|c|c|c|c|c|c|}
\hline \multirow{2}{*}{ Variables } & \multicolumn{2}{|c|}{ Sample IG $(\boldsymbol{N}=\mathbf{7 2})$} & \multicolumn{2}{|c|}{ Sample CG $(\boldsymbol{N}=\mathbf{3 3})$} & \multirow{2}{*}{$\boldsymbol{p}$-value } \\
\cline { 2 - 5 } & $\boldsymbol{n}$ & $\%$ & $\mathbf{n}$ & $\%$ & \\
\hline Age (years old) & & & & & 0.097 \\
\hline $18-39$ & 11 & 15.3 & 1 & 3.0 & \\
\hline $40-69$ & 39 & 54.1 & 22 & 66.7 & \\
\hline$\geq 70$ & 22 & 30.6 & 10 & 30.3 & \\
\hline Gender & & & & & 0.071 \\
\hline Female & 30 & 41.7 & 20 & 60.6 & \\
\hline Male & 42 & 58.3 & 13 & 39.4 & \\
\hline
\end{tabular}




\begin{tabular}{|c|c|c|c|c|c|}
\hline \multirow{2}{*}{ Variables } & \multicolumn{2}{|c|}{ Sample IG $(N=72)$} & \multicolumn{2}{|c|}{ Sample CG $(N=33)$} & \multirow{2}{*}{$p$-value } \\
\hline & $n$ & $\%$ & n & $\%$ & \\
\hline Marital Status & & & & & 0.110 \\
\hline $\begin{array}{l}\text { Married/ } \\
\text { cohabiting }\end{array}$ & 42 & 58.3 & 20 & 60.6 & \\
\hline Single & 10 & 13.9 & 1 & 3.0 & \\
\hline $\begin{array}{l}\text { Separated/ } \\
\text { divorced/ } \\
\text { widow(er) }\end{array}$ & 20 & 27.8 & 12 & 36.3 & \\
\hline Education & & & & & 0.232 \\
\hline Up to $4^{\text {th }}$ grade & 38 & 52.8 & 23 & 69.7 & \\
\hline $5^{\text {th }}$ to $9^{\text {th }}$ grade & 18 & 25.0 & 7 & 21.2 & \\
\hline $10^{\text {th }}$ to $12^{\text {th }}$ grade & 10 & 13.9 & 2 & 6.1 & \\
\hline Higher education & 6 & 8.3 & 1 & 3.0 & \\
\hline Occupation & & & & & 0.393 \\
\hline Employee & 27 & 37.5 & 6 & 18.2 & \\
\hline Unemployed & 7 & 9.7 & 3 & 9.1 & \\
\hline Retired & 38 & 52.8 & 24 & 72.7 & \\
\hline $\begin{array}{l}\text { Preoperative } \\
\text { Information }\end{array}$ & & & & & 0.000 \\
\hline Nurse & 72 & 100 & 4 & 12.1 & \\
\hline Surgeon & 70 & 97.2 & 22 & 66.7 & \\
\hline
\end{tabular}

Source: Own elaboration

In this data collection, concerning clinical variables (Table 3), the colostomy predominated in CG (75.8\%) and in IG (50\%). Most of IG subjects $(62.5 \%)$ had a permanent ostomy. In both groups, cancer was the most predominant as causal disease. The most frequent co-morbidities were hypertension, heart disease, and type 2 Diabetes Mellitus. Before surgery, all participants were independent as to their personal hygiene, using the toilet and having meals.

In the second assessment, $45.9 \%$ of IG and a great part of the CG $(68.7 \%)$ were receiving a complementary treatment (chemotherapy or chemotherapy and radiotherapy). Regarding the stoma site marking, $86.9 \%$ of the IG subjects and $76.7 \%$ of the CG confirmed the stoma was properly located. Likewise, $65.6 \%$ of the IG and $44 \%$ of CG used a mirror to see the stoma. As to the complications in the ostomy and the peristomal skin area, $85 \%$ of the IG did not mention any kind of problem, although $59.4 \%$ of the CG did. The most referred complications by the participants of the two groups are redness/erythema (42.6\%) and stomal pain (16.2\%).
Table 3. Clinical characterization of the sample

\begin{tabular}{|c|c|c|c|c|c|}
\hline \multirow{2}{*}{ Variables } & \multicolumn{2}{|c|}{ Sample IG $(N=72)$} & \multicolumn{2}{|c|}{$\begin{array}{l}\text { Sample CG } \\
(N=33)\end{array}$} & \multirow[t]{2}{*}{$p$-value } \\
\hline & $n$ & $\%$ & $n$ & $\%$ & \\
\hline Type of Stoma & & & & & 0.000 \\
\hline Colostomy & 36 & 50.0 & 25 & 75.8 & \\
\hline Ileostomy & 22 & 30.6 & 1 & 3.1 & \\
\hline Urostomy & 13 & 18.1 & 2 & 6.0 & \\
\hline Others & 1 & 1.4 & 5 & 15.1 & \\
\hline Duration of Ostomy & & & & & 0.002 \\
\hline Permanent & 45 & 62.5 & 13 & 39.4 & \\
\hline Temporary & 27 & 37.5 & 18 & 54.5 & \\
\hline Unknown & & & 2 & 6.1 & \\
\hline Stoma Site Marking* & 61 & 100 & 32 & 0.0 & 0.000 \\
\hline Properly located & 53 & 86.9 & 23 & 76.7 & 0.217 \\
\hline $\begin{array}{c}\text { Skin } \\
\text { Complications* }\end{array}$ & 9 & 15.0 & 19 & 59.4 & 0.000 \\
\hline $\begin{array}{c}\text { Complementary } \\
\text { Treatment* }\end{array}$ & 28 & 45.9 & 22 & 68.7 & 0.017 \\
\hline Use of Mirror* & 40 & 65.6 & 14 & 43.8 & 0.079 \\
\hline
\end{tabular}

* Analyzed in the $2^{\text {nd }}$ assessment (IG $\left.-N=61 ; \mathrm{CG}-N=32\right)$

Source: Own elaboration

Concerning clinical variables, the groups were statistically equivalent $(p>0.05)$ for stoma site properly located and use of the mirror, while statistically different for duration and type of stoma, stomal and peristomal skin complication, complementary treatments, and stoma site marking.

In the first assessment (first month after hospital discharge), statistically significant differences were not observed in the EOAS global score; significant differences were noticed only in the So$\mathrm{cial} /$ Religious Support domain $\left(t_{(97)}=3.121 ; p<0.01\right)$, with the highest score in the control group (Table 4).

Regarding the second assessment (the sixth month after hospital discharge), statistically significant differences were found between the two groups on the total scale $\left(t_{(73)}=-3.679 ; p=\right.$ 0.000 ) and in four out of the six dimensions, $(p<0.01)$, except Social/Religious support and Sexual Interaction (Table 4). 
Table 4. EOAS mean scores and SD by group (IG and CG) in the first and second assessments

\begin{tabular}{|c|c|c|c|c|c|c|c|c|c|}
\hline \multirow[t]{2}{*}{$\begin{array}{l}\text { EOAS Domains and } \\
\text { Overall Scale }\end{array}$} & \multirow[t]{2}{*}{ Gr } & \multicolumn{3}{|c|}{$\begin{array}{c}1^{\text {st }} \text { Assessment } \\
N=105 \\
\text { IG } n=72 \\
\text { CG } n=33\end{array}$} & \multirow[b]{2}{*}{$p$-value } & \multicolumn{3}{|c|}{$\begin{array}{c}2^{\text {nd }} \text { Assessment } \\
N=93 \\
\text { IG } n=61 \\
\text { CG } n=32\end{array}$} & \multirow[b]{2}{*}{$p$-value } \\
\hline & & Mean $(S D)$ & $t$ & $d f$ & & Mean $(S D)$ & $t$ & $d f$ & \\
\hline \multirow{2}{*}{ Self-concept } & IG & 45.15 (20.81) & \multirow{2}{*}{-0.146} & \multirow{2}{*}{83} & \multirow{2}{*}{0884} & $53.37(13.47)$ & \multirow{2}{*}{3.414} & \multirow{2}{*}{87} & \multirow{2}{*}{0.001} \\
\hline & CG & $45.84(21.00)$ & & & & $43.17(13.63)$ & & & \\
\hline \multirow{2}{*}{ Positive Acceptance } & IG & $56.89(16.88)$ & \multirow{2}{*}{0.789} & \multirow{2}{*}{102} & \multirow{2}{*}{0.432} & $64.37(14.75)$ & \multirow{2}{*}{3.114} & \multirow{2}{*}{91} & \multirow{2}{*}{0.002} \\
\hline & CG & 54.29 (12.54) & & & & 54.94 (11.92) & & & \\
\hline \multirow{2}{*}{ Negative Acceptance } & IG & $60.38(18.64)$ & \multirow{2}{*}{-1.164} & \multirow{2}{*}{84} & \multirow{2}{*}{0.248} & $71.61(15.50)$ & \multirow{2}{*}{2.702} & \multirow{2}{*}{78} & \multirow{2}{*}{0.008} \\
\hline & CG & $65.50(18.18)$ & & & & $61.92(16.95)$ & & & \\
\hline \multirow{2}{*}{ Social/ Religious Support } & IG & $70.40(16.88)$ & \multirow{2}{*}{-3.121} & \multirow{2}{*}{97} & \multirow{2}{*}{0.002} & $67.66(13.92)$ & \multirow{2}{*}{-1.220} & \multirow{2}{*}{90} & \multirow{2}{*}{0.226} \\
\hline & CG & $80.06(11.56)$ & & & & $76.25(14.40)$ & & & \\
\hline \multirow{2}{*}{ Sexual Interaction } & IG & $54.01(14.95)$ & \multirow{2}{*}{-0.151} & & & $36.56(13.54)$ & & & \\
\hline & CG & $54.60(14.92)$ & & 68 & 0.880 & 38.11 (12.30) & $-0.4 / /$ & $/ 2$ & 0.635 \\
\hline & IG & $52.24(16.65)$ & & & & 71.23 (19.99) & & & \\
\hline Selt-care & CG & $50.00(12.65)$ & 0.586 & 74 & 0.560 & $53.26(22.95)$ & 2.843 & 73 & 0.006 \\
\hline & IG & $57.70(11.05)$ & م & 67 & 077 & 67.07 (11.22) & 3670 & 73 & 0 \\
\hline Uverall EUAS score & CG & 58.47 (12.12) & -0.258 & 6/ & 0.197 & $57.38(10.42)$ & $3.6 / 9$ & 13 & 0.000 \\
\hline
\end{tabular}

Source: Own elaboration

Table 5. Differences between EOAS mean scores in the first and second assessments by group (IG and CG)

\begin{tabular}{|c|c|c|c|c|c|c|}
\hline \multirow{2}{*}{ EOAS Domains and Overall Scale } & \multicolumn{2}{|c|}{ IG } & \multirow{2}{*}{$p$-value } & \multicolumn{2}{|c|}{ CG } & \multirow{2}{*}{$p$-value } \\
\hline & $t$ & $d f$ & & $t$ & $d f$ & \\
\hline Self-concept & -2.298 & 46 & 0.026 & 0.517 & 29 & 0.609 \\
\hline Positive Acceptance & -3.166 & 59 & 0.002 & -0.344 & 31 & 0.733 \\
\hline Negative Acceptance & -3.852 & 48 & 0.000 & 0.630 & 23 & 0.535 \\
\hline Social/Religious Support & -2.410 & 54 & 0.019 & 2.022 & 31 & 0.052 \\
\hline Sexual Interaction & 28.669 & 48 & 0.000 & 15.546 & 20 & 0.000 \\
\hline Self-care & -6.797 & 60 & 0.000 & -3.328 & 31 & 0.002 \\
\hline Overall EOAS & -5.076 & 38 & 0.000 & 0.599 & 19 & 0.556 \\
\hline
\end{tabular}

Source: Own elaboration 
Between the first and second assessments (Table 5), statistical differences were observed in the IG, both in the EOAS $\left(t_{(38)}=-5.075 ; p<0.001\right)$ and in its domains (Negative Acceptance, Sexual Interaction, and Self-care, $p<0.001$; Self-concept, Positive Acceptance, and Social/Religious Support, $p<0.05)$. It was found that Sexual Interaction domain deteriorated between the first and second assessments. Contrariwise, the CG exhibited no significant differences between the two assessments, both in the overall scale score and in most of its domains. The stoma Self-care domain was the exception; it showed statistically significant improvements between the first and the second assessments, while the Sexual Interaction domain, just as in the IG, worsened with significant differences in the second assessment.

\section{Discussion}

In the first month after hospital discharge, despite the significant effects associated with the causative disease and the stoma, the psychosocial and functional adaptation to the new life circumstances was similarly perceived by and satisfactory to both groups. It is legitimate to admit that the nurses of the clinical contexts, where both IG and CG participants were hospitalized, were sensitized to the particular care for these patients, preparing them to return home. On the other hand, the belief in the self-control of the disease and the ostomy has been positively correlated with the development of autonomy in the first weeks, even without professional and specific help (16), which explains the results obtained in the CG.

The expectation that the adjustment to an ostomy will be sensitive to ETN care and, therefore, more favorable in the IG was not verified. The adjustment process is not easy or quick, which is a reasonable explanation for the absence of differences between both groups one month after hospital discharge. This illustrates that adjustment requires time and continued interdisciplinary care, integrating psychological aspects and support in coping with the stoma $(4,5,14)$.

Comparing the groups six months after hospital discharge, both were different, being the adjustment to the ostomy significantly better in the IG. The differences were found both in the overall score of EOAS and in its components (Self-concept, Positive Acceptance, Negative Acceptance, and Self-care). It is presumed, by our findings, that IG participants accepted their health condition better, had a higher self-concept, were more confident in managing their daily lives, and were more effective in the stoma self-care than the CG. Searching for or provide social/religious support to solve daily life problems was similar in both groups, being the CG more active in the first month after hospital discharge. The demand for social support is widely described as one of the strongest coping strategies for facing change and challenges. It revealed to be a protection factor of the individual identity and a promoter of healthy transition, predicting a better psychosocial adjustment when people experience critical moments such as the creation of a stoma $(13,14)$. We cannot forget the ETN intervention is a kind of social support that IG received, which is why it was attached importance by both groups.

The assessment between the first and sixth month after hospital discharge showed significant improvements in the adjustment to the stoma in the intervention group. For this positive evolution, all EOAS domains contributed significantly. Like other studies showing the association of ostomy care autonomy with high levels of psychosocial adjustment, the adjustment is built in a complex relationship among ostomy acceptance, less discomfort and reluctance to social interaction, and more effective stoma self-care $(12,13)$.

In the control group, the interpretation of the results did not indicate statistically significant changes in the global ostomy adjustment between the two assessments, indicating that their adaptive course was not modified from the first to the second assessments. However, the adoption of new behaviors in ostomy care management was ensured, which was significantly improving over time.

Sexual Interaction stands out as one of the most fragile dimensions, progressively deteriorating in both groups. Our results overlap previous studies, concluding that the ostomy effects on sexual life tend to persist over time. It causes great emotional suffering due to concerns for body image and deterioration or loss of the sexual function, thus influencing the way people express and live their sexuality $(1,2,5,8,26-28)$. Additionally, the impaired sexual function can derive from the surgical approach itself. In the IG, a significant percentage of patients remained with a permanent ostomy. It is known that this type of ostomy, generally associated with extensive surgeries, which can damage or remove fundamental organic structures, has transient or permanent collateral damage in sexual performance in both men and women (29). On the contrary, the temporary ostomy dominated 
the CG that, despite not having such a harmful potential on the physiological structures, suggests people opt for a break in their sexual activity until the stoma closure.

Moreover, the perspective of stoma closure in the near future causes individuals to over-value its reversibility and not to try to adapt. It may happen that the uncertainty about their permanence or closure can make them more vulnerable to fear, anxiety, and feelings of unhappiness, conditioning their daily lives and postponing personal projects $(20,30)$.

Another finding, six months after hospital discharge, is that there was still a considerable percentage of subjects from both the IG and the CG in the complementary treatment of chemotherapy and/or radiotherapy. The harmful effect of complementary therapy on sexuality is well known (27).

The cited literature emphasizes the need for better nursing care regarding the sexuality of patients with an ostomy, not only during admission but also during continued care. It refers to a great lack of information, reinforcing the need for a better professional qualification both in the field of knowledge and in clinical competence $(9,26)$. Cultural and age aspects are very important and should be explored $(16,30)$. Being a very sensitive human dimension to the harmful effects of ostomy surgery, it requires an oriented and meticulous intervention by health professionals, particularly stoma nurses. It is important to note that the percentage of "no answer" in this area ( $16.4 \%$ in the IG and $28.12 \%$ CG) may have conditioned the current study findings. On the other hand, sexual function was not probed before the surgery.

Although the ileostomy is more frequent in the IG, peristomal skin complications prevailed in the CG. In both groups, erythema and stomal pain were the most reported, being these results confirmed by other studies $(16,31)$. The stomal and peristomal skin complications have a longer transition process, both because of its prevalence and severity, and may be deteriorating their comfort and well-being and consequently, their quality of life (31).

Based on the patients' perceptions, the general interpretation of this study results revealed that those who received continuous and systematized stoma care since the preoperative period to the follow-up after leaving the hospital gradually showed higher levels of knowledge of and skills for stoma care, significantly improving their self-care management, social interactions, and self-concept. Probably, the progressive integration of the ostomy into their daily lives improved their self-esteem and body image, positively influencing the psychosocial adjustment (14) between the first and sixth months after hospital discharge. The group that received conventional nursing care did not show evolution in their perception of ostomy adjustment.

These results are similar to other studies that used a control group when observing the benefits of ETN in increased stoma care proficiency and the reduction of peristomal skin complications (16, $31)$. By providing preoperative and follow-up information and individualized assistance, ETN also increases patient's self-confidence and autonomy, contributing to a more quickly psychosocial adjustment, compared to the group that received usual care $(17,30)$.

It can be inferred from these results that the NPET positively influenced the course of the transition for adjustment to the ostomy, being its contribution visible in the sixth month after hospital discharge.

Globally, healthier outcome indicators are present in IG, such as those perceived in ostomy acceptance, positive self-concept, and self-care proficiency, experiencing a comparatively more positive transition process than CG people. Thus, systematized nursing therapeutics, as a complement, helped the IG to become autonomous in stoma care and better manage other life changes, promoting a healthier adjustment (14).

The results of this study allowed us to better understand how some people with an ostomy interpret changes in their health and life, and how the structured and continuous nursing intervention received can influence their adjustment to the new condition.

\section{Study limitations}

The study limitations to be considered are the small sample size and the difference in the number of subjects between the groups; no baseline since instruments were applied just after the surgery, before discharge; regarding the sexuality domain, the high rate of values not provided by the two groups, and the absence of pre-surgery data.

\section{Recommendations}

To guarantee the reliability of the results and generalize after the study, an experimental study would be more robust. The 
study suggests that ostomy adjustment improves significantly if patients have access to differentiated care from the preoperative period to continued care, particularly if the ETN assistance is systematized in intervention protocols. Outcome assessment using specific and reliable instruments is also essential. Such a statement poses a challenge to the continuity of research with other designs that explore this problem from other views.

\section{Conclusion}

It was confirmed that people who benefited from an organized and continuous ETN intervention from preoperative to follow-up care experienced significant improvements in adjusting to the stoma between the first and the sixth month after hospital discharge. These improvements were significantly higher compared to those patients who did not have this intervention (CG), as they maintained improvement levels similar to those of the first assessment.

As a final note, it is possible to assume that the changes and differences in the adjustment to an ostomy perceived by the intervention group compared to the control group between the first and sixth month after discharge were sensitive to the effects of the systematized ETN intervention on research participants.

Conflict of interest: None.

\section{References}

1. Cesaretti IUR, Leite MG, Fillipin MJ, Santos VLG. Cuidando de pessoas nos períodos pré, trans e pós-operatórios de cirurgias geradoras de estomias. In: Santos VLCG, Cesaretti IUR, editors. Assistência em Estomaterapia Cuidando a pessoa com ostomia. 2nd ed. S. Paulo: Editora Atheneu; 2015. ISBN 978-85-388-0630-1

2. Costa VF, Eufrásio C, Salomé GM, Ferreira LM. Assessing the body image and subjective wellbeing of ostomists living in Brazil. Gastrointestinal Nursing. 2014;12(5). DOI: https://doi.org/10.12968/gasn.2014.12.5.37

3. Reis FF. Transição para a vivência com ostomia: intervenções de enfermagem [dissertation on the Internet]. Porto: Instituto de Ciências Biomédicas, Universidade do Porto; 2016 [cited 2019 Nov 5]. Available from: https://repositorioaberto.up.pt/handle/10216/5403

4. Villa G, Manara D, Brancato T, Rocco G, Stievano VE, Alvaro R. Life with a urostomy: A phenomenological study. Applied Nursing Research. 2017;39(1):46-52. DOI: https://doi.org/10.1016/j.apnr.2017.10.005

5. Ceylan H, Vural F. Living with stoma - a phenomenological study. J Nurs Res Pract. [Internet]. 2017 [cited 2019 Nov 05];1(1):06-12. Available from: https://www.pulsus.com/scholarly-articles/living-with-stoma--a-phenomenologicalstudy.pdf

6. Shrief SE, Mokhtar MI. Effect of structured teaching guidelines on patient's knowledge, practice, and self-efficacy regarding colostomy care. International Journal of Advance Research in Nursing [Internet]. 2019 [cited 2019 Nov 05];2(2):4151. Available from: http://www.nursingjournal.net/article/view/56/1-2-25

7. Pereira N, Rebelo BMA. Experiência Vivida dos Sobreviventes de Cancro do Cólon e Reto após Tratamento com Intenção Curativa: Revisão sistemática da literatura. Pensar Enfermagem [Internet]. 2012 [cited 2019 Nov 05];16(1):31-50. Available from: http://pensarenfermagem.esel.pt/files/PE16-2_Artigo2_31-50.pdf

8. Ang SGM, Chen H-C, Siah RJC, He H-G, Klainin-Yobas P. Stressors relating to patient psychological health following stoma surgery: an integrated literature review. Oncology Nursing Forum. 2013;40(6):587-594. DOI: https://doi. org/10.1188/13.ONF.587-594

9. Sousa CF, Brito DC, Castelo Branco MZP. Depois da colostomia... vivências das pessoas portadoras. Revista Enfermagem em Foco [Internet]. 2012 [cited 2019 Nov 05];3(1):12-5. Available from: http://revista.cofen.gov.br/index.php/enfermagem/article/view/213

10. International Council of Nurses. Ordem dos Enfermeiros. Classificação Internacional para a Prática de Enfermagem. CIPE Versão 1.0. Lisboa: 2006. ISBN 92-95040-36-8. 
11. Mota MS, Gomes GC, Petuco VM, Heck RM, Barros EL, Gomes VLdO. Facilitadores do processo de transição para o autocuidado da pessoa com estoma: subsídios para Enfermagem. Rev Esc Enferm. 2015;49(1):82-8. DOI: https://doi. org/10.1590/S0080-623420150000100011

12. Cheng F, Meng A, Yang LF, Zhang Y. The Correlation between Ostomy Knowledge and Self-Care Ability with Psychosocial Adjustment in Chinese Patients with a Permanent Colostomy: A Descriptive Study. Journal Ostomy Wound Management [Internet]. 2013 [cited 2019 Nov 05];59(7):35-8. Available from: https://pdfs.semanticscholar.org/d637/ aae322603ad3b21da095423459a84239b6c9.pdf

13. Simmons KL, Smith JA, Bobb K-A, Liles LLM. Adjustment to colostomy: stoma acceptance, stoma care self-efficacy and interpersonal relationships. Journal of Advanced Nursing. 2007;60(6):627-35. DOI: https://doi.org/10.1111/j.13652648.2007.04446.x

14. Meleis AI. Transitions Theory. Middle-Range and Situation-Specific Theories in Nursing Research and Practice. New York: Springer Publishing Company; 2010. ISBN 978-0-8261-0534-9

15. Silva J, Sonobe HM, Buetto LS, Santos MG, Lima MS, Sasaki VDM. Estratégias de ensino para o autocuidado de estomizados intestinais. Rev Rene. 2014;15(1):166-73. DOI: https://doi.org/10.15253/2175-6783.2014000100021

16. Zhou H, Ye Y, Qu H, Zhou H, Gu S, Wang T. Effect of ostomy care team intervention on patients with ileal conduit. J Wound Ostomy Continence Nurs. 2019;46(5):413-417. DOI: https://doi.org/10.1097/WON.0000000000000574

17. Coca C, Fernández de Larrinoa I, Serrano R, García-Llana H. The Impact of Specialty Practice Nursing Care on HealthRelated Quality of Life in Persons with Ostomies. Journal of Wound, Ostomy \& Continence Nursing. 2015;42(3):257-263 DOI: https://doi.org/10.1097/WON.0000000000000126

18. Mota MS, Reis TRS, Gomes GC, Barros EJL, Nörnberg PKO, Chagas MCS. Stomized patients' perception of the stomatherapy service: a descriptive study. Online Brazilian Journal of Nursing. 2015;14(3):238-47. DOI: https://doi. org/10.17665/1676-4285.2015v14n3

19. Miranda LSG, Carvalho AS, Paz EPA. Quality of life of ostomized person: relationship with the care provided in stomatherapy nursing consultation. Esc. Anna Nery [Internet]. 2018 [cited 2019 Nov 05];22(4):e20180075. DOI: https:// doi.org/10.1590/2177-9465-ean-2018-0075

20. Danielsen AK, Burcharth JR, Rosenberg J. Patient education has a positive effect in patients with a stoma: a systematic review. Colorectal Disease. 2013;15(6):276-83. DOI: https://doi.org/10.1111/codi.12197

21. McCloskey JC, Bulechek GM. Classificação das intervenções de enfermagem. 3rd ed. Porto Alegre: Artmed; 2004. ISBN 85-7307-819-72000

22. Polit DF, Beck CT. Fundamentos de pesquisa em enfermagem: Avaliação de evidências para a prática de enfermagem. 7th ed. Porto Alegre: Artmed; 2011. ISBN 978-85-363-2545-3

23. Sousa CF, Santos C, Graça LC. Construção e validação de uma escala de adaptação a ostomia de eliminação. Revista de Enfermagem Referência [Internet]. 2015 [cited Nov 05];6(4):21-30. DOI: https://doi.org/10.12707/RIV14021

24. Fernandes ADBF, Lopes AM, Falcão LM, Silva GRF. Adaptação cultural da escala de adaptação à ostomia de eliminação para uso no Brasil. Texto Contexto Enferm [Internet]. 2019 [cited 2020 Feb. 11];28:e20180234. DOI: https://doi. org/10.1590/1980-265X-TCE-2018-0234

25. Pestana MH, Gageiro JN. Análise de dados para ciências sociais - a complementaridade do SPSS. 6th ed. Lisboa: Edições Sílabo, Lda; 2014. ISBN 978-972-618-775-2

26. Vural F, Harputlu D, Karayurt O, Suler G, Edeer A, Ucer C, et al. The Impact of an Ostomy on the Sexual Lives of Persons with Stomas: A Phenomenological Study. Journal of Wound, Ostomy, and Continence Nursing. 2016;43(4):381-84. DOI: https://doi.org/10.1097/WON.0000000000000236

27. Breukink SO, Donovan KA. Physical and Psychological Effects of Treatment on Sexual Functioning in Colorectal Cancer Survivors. Journal of Sexual Medicine. 2013;10(1):74-83. DOI: https://doi.org/10.1111/jsm.12037

28. Vonk-Klaassen S, Vocht M, Ouden H, Eddes M, Schuurmans E. Ostomy-related problems and their impact on quality of life of colorectal cancer ostomates: A systematic review. Quality of Life Research. 2016;25(1):125-33. DOI: https://doi. org/10.1007/s11136-015-1050-3 
29. El-Tawil AM, Nightingale P. Living with Stoma: Long-term Effects on Patients' Quality of Life. J Clin Cell Immunol. 2013;4(145):1-5. DOI: https://doi.org/10.4172/2155-9899.1000145

30. Karabulut HK, Dinç L, Karadag A. Effects of planned group interactions on the social adaptation of individuals with an intestinal stoma: a quantitative study. Journal of Clinical Nursing. 2014;23(19-20):2800-13. DOI: https://doi. org/10.1111/jocn. 12541

31. Pittman JA. Ostomy complications and associated risk factors: development and testing of two instruments [dissertation]. Indiana University; 2011 [cited 2019 Nov 08]. Available from: https://pdfs.semanticscholar.org/2e6d/dfc3971afd3025c13b60f150a57811618564.pdf?_ga=2.19417656.1043655915.1573247262-717770295.1560791991 